\title{
Corrigendum: Sarcoidosis is associated with a truncating splice site muta- tion in the gene BTNL2
}

R Valentonyte, J Hampe, K Huse, P Rosenstiel, M Albrecht, A Stenzel, M Nagy, K I Gaede, A Franke, R Haesler, A Koch, T Lengauer, D Seegert, N Reiling, S Ehlers, E Schwinger, M Platzer, M Krawczak, J Müller-Quernheim, M Schürmann \& S Schreiber

Nat. Genet. 37, 357-364 (2005).

In the version of Supplementary Table 3 initially published online, the nomenclature of DQB and DPB alleles was partly incorrect. The errors have now been corrected and Supplementary Table 3 has been replaced. Neither the stratified analyses that highlighted the independence of the BTNL2 effect from the two HLA loci (Supplementary Table 3 online) nor any other conclusions of the manuscript were affected by these mistakes.

\section{Corrigendum: Frequent somatic mutations of the transcription factor ATBF1} in human prostate cancer

X Sun, H F Frierson, C Chen, C Li, Q Ran, K B Otto, B L Cantarel, R L Vessella, A C Gao, J Petros, Y Miura, J W Simons \& J-T Dong Nat. Genet. 37, 407-412 (2005).

The name of the seventh author was incorrect. The correct name is Brandi L Cantarel.

Erratum: A functional variant in FCRL3, encoding Fc receptor-like 3, is associated with rheumatoid arthritis and several autoimmunities

Y Kochi, R Yamada, A Suzuki, J B Harley, S Shirasawa, T Sawada, S-C Bae, S Tokuhiro, X Chang, A Sekine, A Takahashi, T Tsunoda,
Y Ohnishi, K M Kaufman, C P Kang, C Kang, S Otsubo, W Yumura, A Mimori, T Koike, Y Nakamura, T Sasazuki \& K Yamamoto Nat. Genet. 37, 478-485 (2005).

In the replication study confirming the association between $\mathrm{fcrl3} 3(-169 \mathrm{C} \rightarrow \mathrm{T})$ and rheumatoid arthritis susceptibility, the allele frequency of fcrl3_3 in controls is 0.36 . 